\title{
Photosynthetic Active Pigments Changes in Norway Spruce (Picea abies) under the Different Acclimation Irradiation and Elevated $\mathrm{CO}_{2}$ Content
}

\author{
Miroslav Kvíčala, ${ }^{1}$ Eva Lacková, ${ }^{2}$ and Lenka Urbancová ${ }^{2}$ \\ ${ }^{1}$ Department of Non-Ferrous Materials, Rafination and Recyclation, VŠB-Technical University of Ostrava (VŠB-TU Ostrava), \\ 17. listopadu 15/2172, 70833 Ostrava, Czech Republic \\ ${ }^{2}$ Institute of Environmental Engineering, VŠB-Technical University of Ostrava (VŠB-TU Ostrava), 17. listopadu 15/2172, \\ 70833 Ostrava, Czech Republic
}

Correspondence should be addressed to Miroslav Kvíčala; miroslav.kvicala@vsb.cz

Received 27 January 2014; Accepted 17 February 2014; Published 6 March 2014

Academic Editors: W. K. Jo and A. Waseem

Copyright (C) 2014 Miroslav Kvíčala et al. This is an open access article distributed under the Creative Commons Attribution License, which permits unrestricted use, distribution, and reproduction in any medium, provided the original work is properly cited.

Photosynthetic active pigments content (chlorophylls and carotenoids) in Norway spruce (Picea abies) needles was measured by absorption spectroscopy. Norway spruce was exposed to low and high photosynthetic active radiation and ambient and elevated $\mathrm{CO}_{2}$ concentration. It was investigated that combination of low photosynthetic active radiation and elevated concentration of $\mathrm{CO}_{2}$ resulted in stimulation of chlorophylls and carotenoids production. Combination of high photosynthetic active radiation and elevated $\mathrm{CO}_{2}$ concentration led to overall chlorophylls and carotenoids content decrease. Moreover, specific leaf area trend could be used as a potentially reliable indicator of plant stress response.

\section{Introduction}

Higher plants are permanently stressed by different kinds of natural and artificial factors. These stress factors could be drought, rapid temperature changes, diseases, herbicides, intraspecies and interspecies competition, insect, high salinity, low soil minerals content, and elevated carbon dioxide $\left(\mathrm{CO}_{2}\right)$ concentrations. During the last 100 years $\mathrm{CO}_{2}$ concentration in atmosphere increased dramatically as a result of human activities. Actual $\mathrm{CO}_{2}$ concentration $350 \mu \mathrm{mol}\left(\mathrm{CO}_{2}\right) \cdot \mathrm{mol}^{-1}$ is definitely not the fixed value and is going to increase in the future, Busch et al. [1]. It is expected that $\mathrm{CO}_{2}$ concentration will be two times higher than at the present (King et al. [2]). With respect to this expectation $\mathrm{CO}_{2}$ concentration influence on photosynthetic apparatus of the higher plants is a subject of interest for modern ecophysiology, Pittermann et al. [3], Gerhart et al. [4], and Whitehead [5].

\section{Experimental Methods}

One-year-old trees of Norway spruce (Picea abies) were used in this study. All plants were grown in soil substrate. Distilled water was used during the whole experiment. All plants were grown in growth chamber HB 1014 (Bio Line, Heraeus, Germany). Light regime in growth chamber was 8 hours of darkness and 16 hours of light. In the growth chamber there were stable conditions (humidity $65 \%$ and temperature $20^{\circ} \mathrm{C}$ ). The first group of Norway spruce trees was adapted to high irradiation $1200 \mu \mathrm{mol} \cdot \mathrm{m}^{-2} \cdot \mathrm{s}^{-1}$ and atmospheric $\mathrm{CO}_{2}$ concentration $350 \mu \mathrm{mol}\left(\mathrm{CO}_{2}\right) \cdot \mathrm{mol}^{-1}$ for 25 days. Thereafter irradiation remained the same, but $\mathrm{CO}_{2}$ concentration was increased up to $700 \mu \mathrm{mol}\left(\mathrm{CO}_{2}\right) \cdot \mathrm{mol}^{-1}$. These conditions were kept for 11 days. The second group of Norway spruce trees was growing under the low irradiation $100 \mu \mathrm{mol} \cdot \mathrm{m}^{-2} \cdot \mathrm{s}^{-1}$ and atmospheric $\mathrm{CO}_{2}$ concentration for 25 days. After that irradiation remained the same, but $\mathrm{CO}_{2}$ concentration 


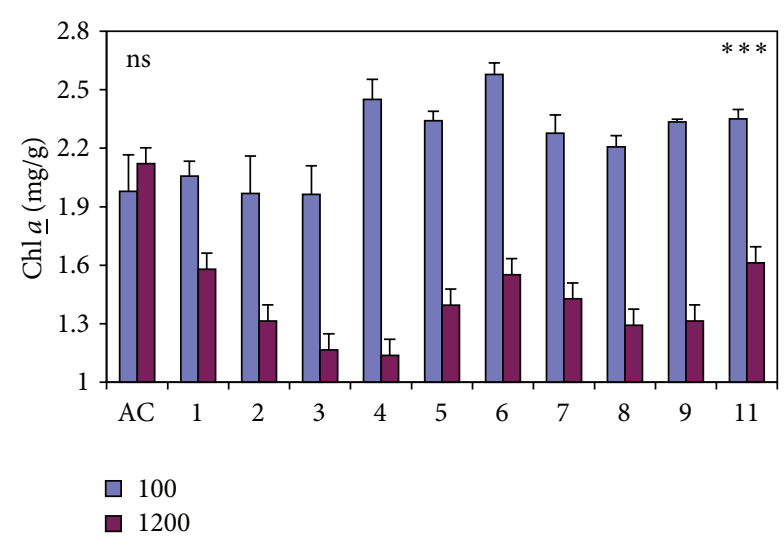

FIGURE 1: Chl $a$ content in Norway spruce needles associated with

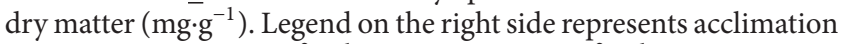
irradiance $100 \mu \mathrm{mol} \cdot \mathrm{m}^{-2} \cdot \mathrm{s}^{-1}$ and $1200 \mu \mathrm{mol} \cdot \mathrm{m}^{-2} \cdot \mathrm{s}^{-1}$. AC-ambient concentration of $\mathrm{CO}_{2}-350 \mu \mathrm{mol} \cdot \mathrm{mol}^{-1}$, days 1-11 (elevated concentration of $\mathrm{CO}_{2}: 700 \mu \mathrm{mol} \cdot \mathrm{mol}^{-1}$ ).

increased up to $700 \mu \mathrm{mol}\left(\mathrm{CO}_{2}\right) \cdot \mathrm{mol}^{-1}$. These conditions were kept also for 11 days. The first samples collection was realized the last day before $\mathrm{CO}_{2}$ concentration was increased. Thereafter, samples were collected every day of experiment (with one exception-day 10th). Samples were taken from four different trees of Norway spruce for every group. Needles were randomly collected from the second whorl. The digital scanner and analytical weighter were used for determination of specific leaf area. Absorption measurements were realized using UV-VIS spectrophotometer (UV/VIS 550, UNICAM, England). Pigments content was calculated according to equations proposed by Lichtenthaler [6] as an average of six samples. All results are demonstrated as an average \pm standard deviation (SD).

All data were statistically analyzed using Minitab 15 software. The three significance levels which were used are $\alpha=0,05$ (marked as- $-*), \alpha=0,01(* *)$, and $\alpha=0,001(* * *)$. Nonsignificant differences were marked such as ns.

\section{Results and Discussion}

From the kinetics of chlorophyll a $(\mathrm{Chl} \underline{a})\left(\mathrm{mg} \cdot \mathrm{g}^{-1}\right)$ content changes in Norway spruce needles it is clear that different acclimation irradiation $\left(100 \mu \mathrm{mol} \cdot \mathrm{m}^{-2} \cdot \mathrm{s}^{-1}\right.$ and $1200 \mu \mathrm{mol} \cdot \mathrm{m}^{-2} \cdot \mathrm{s}^{-1}$ ) and atmospheric concentration $350 \mu$ $\mathrm{mol}\left(\mathrm{CO}_{2}\right) \cdot \mathrm{mol}^{-1}$ did not result in significant changes in $\mathrm{Chl} \underline{a}$ content relative to dry matter. In the case of Norway spruce exposed to both acclimation irradiation and elevated $\mathrm{CO}_{2}$ concentration $\left(700 \mu \mathrm{mol}\left(\mathrm{CO}_{2}\right) \cdot \mathrm{mol}^{-1}\right)$ the significant difference in Chl $\underline{a}$ content which is (31,5\%) in favor of lower irradiation was observed, but there is also difference for the same irradiation and different $\mathrm{CO}_{2}$ concentrations; see Figure 1.

It could be expected that in the case of lower irradiation and increased $\mathrm{CO}_{2}$ concentration photosynthetic activity is optimized due to the $\mathrm{Chl} \underline{a}$ content increase in reaction centers (RC) of photosystem II (PS II). On the contrary,

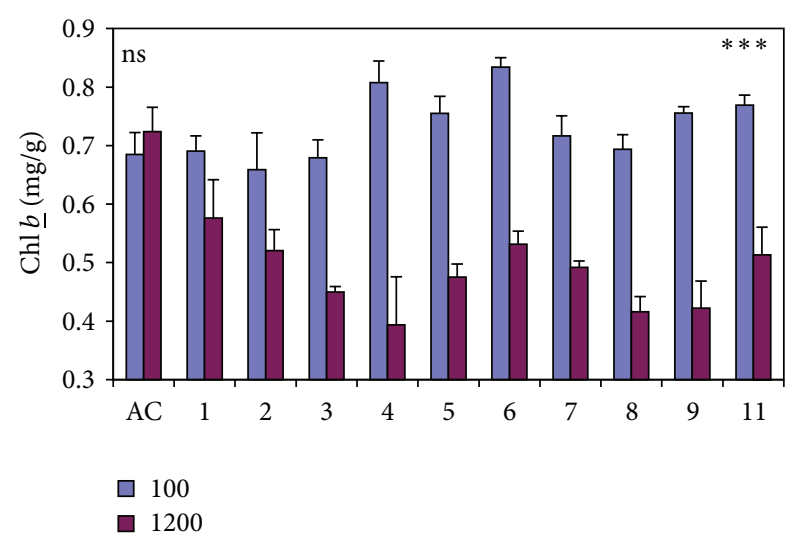

FIgURE 2: Chl $b$ content in Norway spruce needles associated with

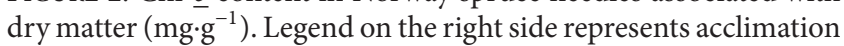
irradiance $100 \mu \mathrm{mol} \cdot \mathrm{m}^{-2} \cdot \mathrm{s}^{-1}$ and $1200 \mu \mathrm{mol} \cdot \mathrm{m}^{-2} \cdot \mathrm{s}^{-1}$. AC-ambient concentration of $\mathrm{CO}_{2}-350 \mu \mathrm{mol} \cdot \mathrm{mol}^{-1}$, days 1-11 (elevated concentration of $\left.\mathrm{CO}_{2}: 700 \mu \mathrm{mol} \cdot \mathrm{mol}^{-1}\right)$.

combination of $1200 \mu \mathrm{mol} \cdot \mathrm{m}^{-2} \cdot \mathrm{s}^{-1}$ irradiation and elevated $\mathrm{CO}_{2}$ concentration is a stressful combination that led to decrease of RC PS II photosynthetic activity.

The kinetics of chlorophyll b $(\mathrm{Chl} \underline{b})\left(\mathrm{mg}_{\mathrm{g}} \mathrm{g}^{-1}\right)$ content in Norway spruce needles is similar to that of Chl $\underline{a}$. The combination of $1200 \mu \mathrm{mol} \cdot \mathrm{m}^{-2} \cdot \mathrm{s}^{-1}$ irradiation and elevated $\mathrm{CO}_{2}$ concentration resulted in significantly lower value of $\mathrm{Chl} \underline{b}$ compared to the same $\mathrm{CO}_{2}$ concentration and $100 \mu \mathrm{mol} \cdot \mathrm{m}^{-2} \cdot \mathrm{s}^{-1}$ irradiation. On the contrary, elevated $\mathrm{CO}_{2}$ concentration combined with lower irradiation resulted in higher content of Chl $\underline{b}$ in light harvesting complexes (LHC) of PS II. Generally said, $100 \mu \mathrm{mol} \cdot \mathrm{m}^{-2} \cdot \mathrm{s}^{-1}$ irradiation is too low for optimal function of Norway spruce photosystem and atmospheric $\mathrm{CO}_{2}$ concentration; see Figure 2.

The kinetics of carotenoids $(\mathrm{Carx}+\mathrm{c})\left(\mathrm{mg}^{\mathrm{g}} \mathrm{g}^{-1}\right)$ content changes in Norway spruce needles demonstrates significant differences in carothenoids content for atmospheric $\mathrm{CO}_{2}$ concentration. Carx $+\mathrm{c}$ reflects protective mechanism of Norway spruce during different irradiation. It could be said that $1200 \mu \mathrm{mol} \cdot \mathrm{m}^{-2} \cdot \mathrm{s}^{-1}$ irradiation is not a stress factor for Norway spruce, because higher irradiation resulted only in the higher content of Carx $+c$, but it did not influence chlorophylles content. So the $\mathrm{CO}_{2}$ assimilation capacity remained stable. Combination of increased irradiation and elevated $\mathrm{CO}_{2}$ resulted in the significant decrease of Carx $+c$ content. This fact could be interpreted as a consequence of photosynthetic apparatus reduction (both $\mathrm{Chl} \underline{a}$ from RC PS II and Chl $\underline{b}$ from LHC PS II were degradated); see Figure 3.

The kinetics of $\mathrm{Chl} \underline{a} / \underline{b}$ rate in the Norway spruce needles did not show a significant difference for an atmospheric $\mathrm{CO}_{2}$ concentration. It could be said that $1200 \mu \mathrm{mol} \cdot \mathrm{m}^{-2} \cdot \mathrm{s}^{-1}$ irradiation is not high enough to become a stress factor for Norway spruce. Once again, also this rate change may be interpreted as an indicator of the plant irradiation stress. Although $\mathrm{Chl} \underline{a} / \underline{b}$ rate increased slightly during the experiment, those differences were statistically nonsignificant. However, the 


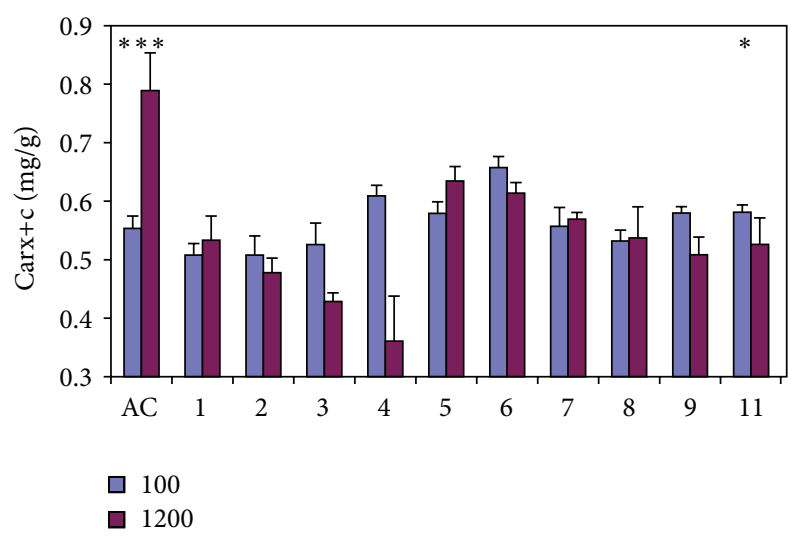

FIGURE 3: Carx $+c$ content in Norway spruce needles associated with dry matter $\left(\mathrm{mg}^{-1} \mathrm{~g}^{-1}\right)$. Legend on the right side represents acclimation irradiance $100 \mu \mathrm{mol} \cdot \mathrm{m}^{-2} \cdot \mathrm{s}^{-1}$ and $1200 \mu \mathrm{mol} \cdot \mathrm{m}^{-2} \cdot \mathrm{s}^{-1}$. AC-ambient concentration of $\mathrm{CO}_{2}-350 \mu \mathrm{mol} \cdot \mathrm{mol}^{-1}$, days 1-11 (elevated concentration of $\mathrm{CO}_{2}: 700 \mu \mathrm{mol} \cdot \mathrm{mol}^{-1}$ ).

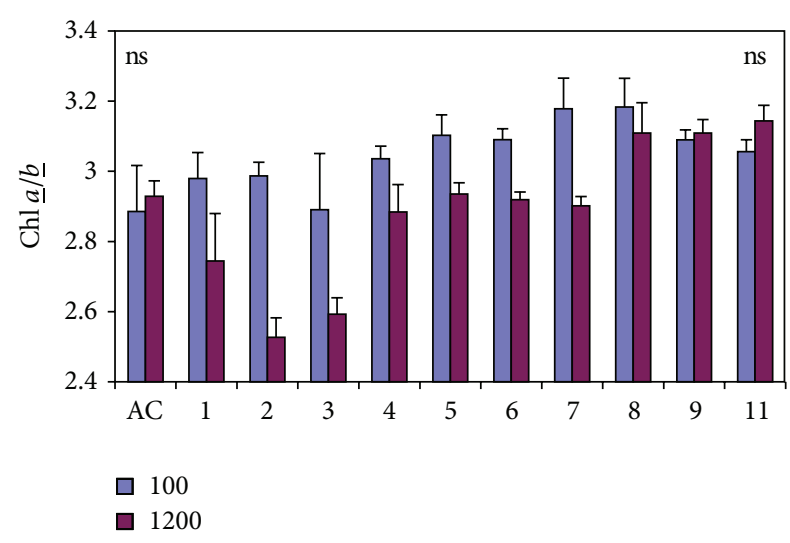

Figure 4: Chl $\underline{a} / \underline{b}$ content rate in Norway spruce needles. Legend on the right side represents acclimation irradiance $100 \mu \mathrm{mol} \cdot \mathrm{m}^{-2} \cdot \mathrm{s}^{-1}$ and $1200 \mu \mathrm{mol} \cdot \mathrm{m}^{-2} \cdot \mathrm{s}^{-1}$. AC: ambient concentration of $\mathrm{CO}_{2}$, days 1-11 (elevated concentration of $\mathrm{CO}_{2}: 700 \mu \mathrm{mol} \cdot \mathrm{mol}^{-1}$ ).

chlorophylls degradation was parallel process, which was realized in LHC antennas and reaction centers. Slightly increasing Chl $\underline{a} / \underline{b}$ rate indicates that light harvesting Chl $\underline{b}$ is degradated preferably and $\mathrm{Chl} \underline{a}$ degradation is follow-up process; see Figure 4.

Different irradiation and $\mathrm{CO}_{2}$ concentration resulted in the statistically significant changes in specific leaf area (SLA) of the Norway spruce needles. Meanwhile, combination of the ambient $\mathrm{CO}_{2}$ concentration and $1200 \mu \mathrm{mol} \cdot \mathrm{m}^{-2} \cdot \mathrm{s}^{-1}$ irradiation led to SLA increase; this fact may be interpreted as a proof of photosynthesis yield optimization. On the contrary, synergistic effect of elevated $\mathrm{CO}_{2}$ concentration and $1200 \mu \mathrm{mol} \cdot \mathrm{m}^{-2} \cdot \mathrm{s}^{-1}$ irradiation resulted in a significant SLA decrease that could be interpreted as a result of the oversaturated photosystem; see Figure 5.

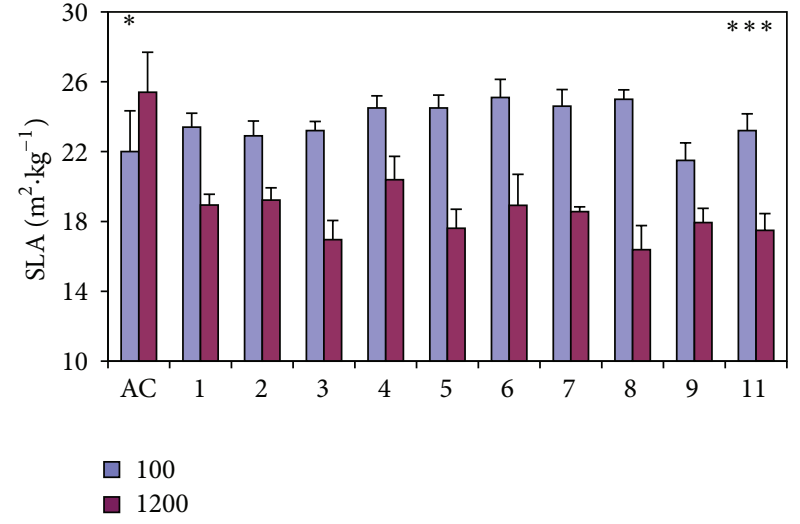

FIgURE 5: Specific leaf area $\left(\mathrm{m}^{2} \cdot \mathrm{kg}^{-1}\right)$ of Norway spruce needles. Legend on the right side represents acclimation irradiance $100 \mu \mathrm{mol} \cdot \mathrm{m}^{-2} \cdot \mathrm{s}^{-1}$ and $1200 \mu \mathrm{mol} \cdot \mathrm{m}^{-2} \cdot \mathrm{s}^{-1}$. AC-ambient concentration of $\mathrm{CO}_{2}-350 \mu \mathrm{mol} \cdot \mathrm{mol}^{-1}$, days 1-11 (elevated concentration of $\left.\mathrm{CO}_{2}: 700 \mu \mathrm{mol} \cdot \mathrm{mol}^{-1}\right)$.

\section{Conclusions}

This paper deals with photosynthetic active pigments content in the Norway spruce needles under the different irradiation and $\mathrm{CO}_{2}$ concentration. It was investigated that an acclimation irradiation $1200 \mu \mathrm{mol} \cdot \mathrm{m}^{-2} \cdot \mathrm{s}^{-1}$ is not a stress factor for photosynthetic apparatus of the Norway spruce in the case of the atmospheric $\mathrm{CO}_{2}$ concentration. The difference between 100 and $1200 \mu \mathrm{mol} \cdot \mathrm{m}^{-2} \cdot \mathrm{s}^{-1}$ irradiation could be balanced by a higher content of protective carotenoids pigments. On the contrary, combination of the $1200 \mu \mathrm{mol} \cdot \mathrm{m}^{-2} \cdot \mathrm{s}^{-1}$ irradiation and elevated $\mathrm{CO}_{2}$ concentration resulted in a significant decrease of the Chl $a$ from RC PS II and Chl $b$ from LHC PS II due to the oversaturation of the plant photosynthetic apparatus. It can be said that low irradiation in combination with elevated $\mathrm{CO}_{2}$ concentration may lead to optimization of the $\mathrm{CO}_{2}$ assimilation. However, in the case of higher irradiation level and elevated $\mathrm{CO}_{2}$ concentration, it leads to the photosynthetic depression.

\section{Conflict of Interests}

The authors declare that there is no conflict of interests regarding the publication of this paper.

\section{Acknowledgments}

This paper has been elaborated in the framework of the Project Opportunity for young researchers, Reg. no. CZ.1.07/2.3.00/30.0016, supported by Operational Programme Education for Competitiveness and cofinanced by the European Social Fund and the state budget of the Czech Republic. This paper was created in the Project no. LO1203 "Regional Materials Science and Technology Centre - Feasibility Program" funded by Ministry of Education, Youth and Sports of the Czech Republic. 


\section{References}

[1] F. A. Busch, T. L. Sage, A. B. Cousins, and R. F. Sage, " $\mathrm{C}_{3}$ plants enhance rates of photosynthesis by reassimilating photorespired and respired $\mathrm{CO}_{2}$," Plant, Cell \& Environment, vol. 31, pp. 200212, 2012.

[2] A. W. King, W. R. Emanuel, and W. M. Post, "Projecting future concentrations of atmospheric $\mathrm{CO}_{2}$ with global carbon cycle models: The importance of simulating historical changes," Environmental Management, vol. 16, no. 1, pp. 91-108, 1992.

[3] J. Pittermann, S. A. Stuart, Dawson, and T. E. Moreau A, "Cenozoic climate change shaped the evolutionary ecophysiology of the Cupressaceae conifers," Proceedings of the National Academy of Sciences of the United States of America, vol. 109, no. 24, pp. 9647-9652, 2012.

[4] L. M. Gerhart, J. M. Harris, J. B. Nippert, D. R. Sandquist, and J. K. Ward, "Glacial trees from the La Brea tar pits show physiological constraints of low $\mathrm{CO}_{2}$," New Phytologist, vol. 194, no. 1, pp. 63-69, 2012.

[5] A. Whitehead, "Comparative genomics in ecological physiology: toward a more nuanced understanding of acclimation and adaptation," The Journal of Experimental Biology, vol. 215, pp. 792-800, 2012.

[6] H. K. Lichtenthaler, "Chlorophylls and carotenoids: pigments of photosynthetic biomembranes," Methods in Enzymology, vol. 148, pp. 350-382, 1987. 

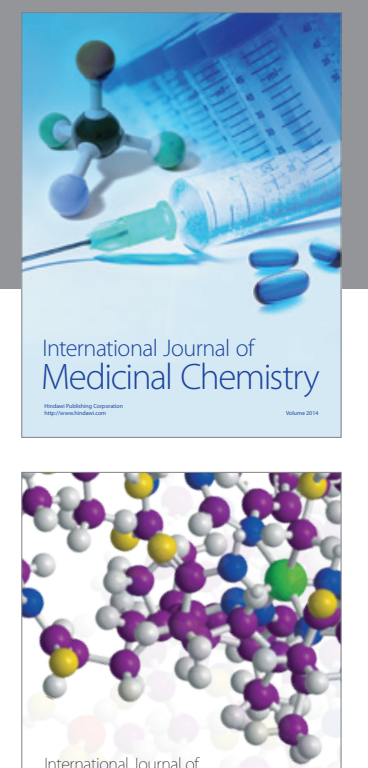

\section{Carbohydrate} Chemistry

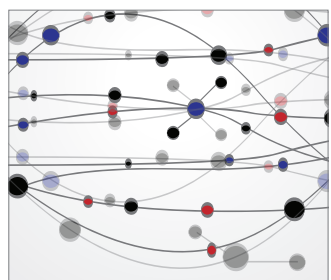

The Scientific World Journal
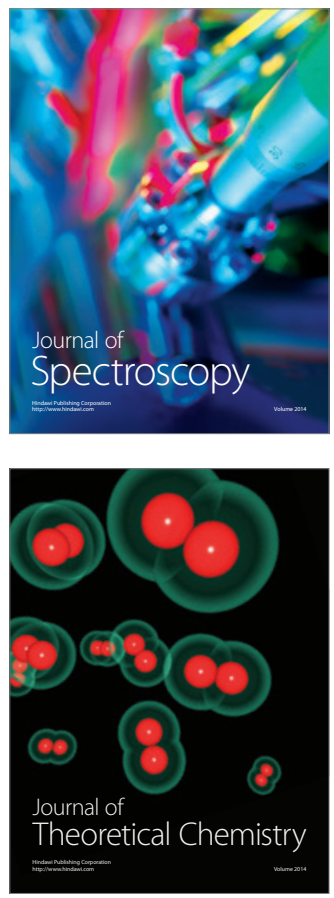
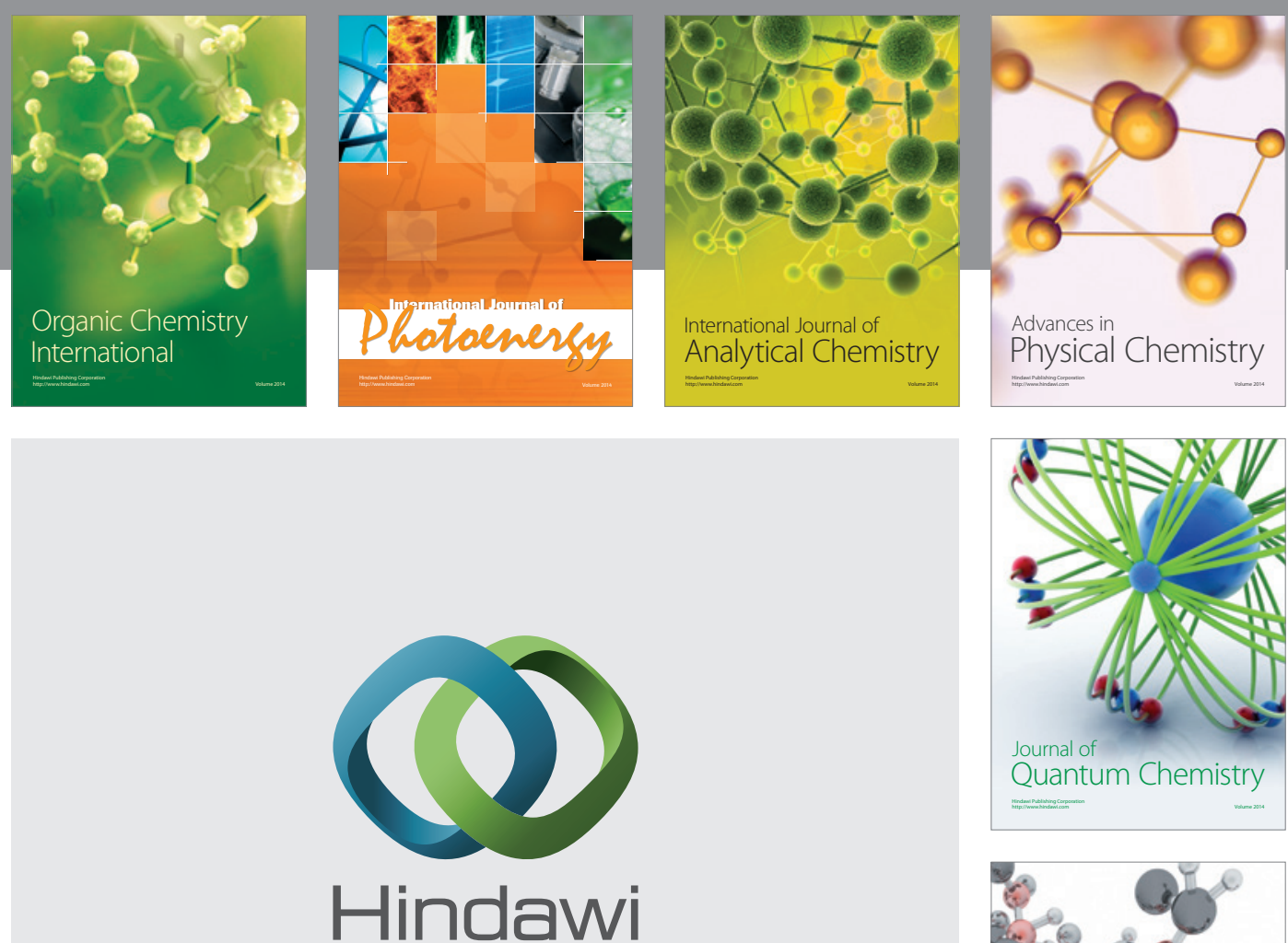

Submit your manuscripts at

http://www.hindawi.com

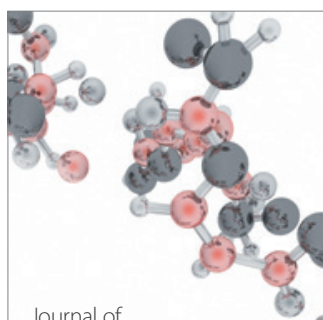

Analytical Methods

in Chemistry

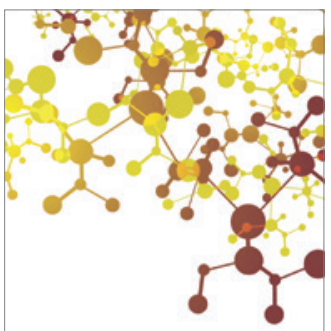

Journal of

Applied Chemistry

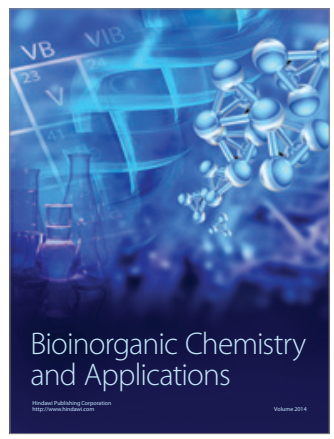

Inorganic Chemistry
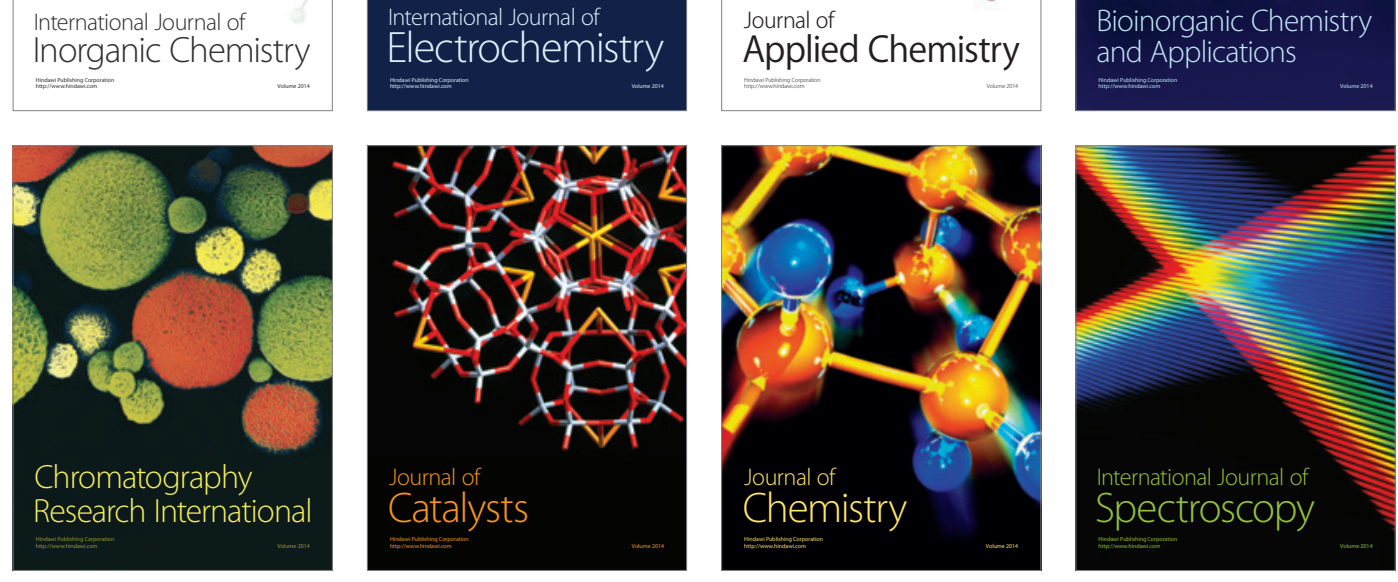